\title{
University education in Ghana: A privilege or a right?
}

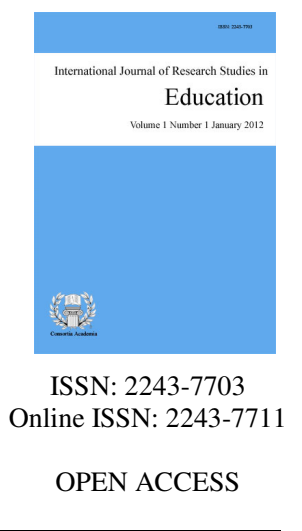

Acheampong, Phinihas

Beijing Normal University, China (aphinihas@yahoo.com)

Kayange, Jimmy Jaston

Beijing Normal University, China (jastonjimmy@yahoo.com)

\section{Abstract}

The study seeks to explore the cost of university education in Ghana. The rationale is premised on the fact that education is a human right which must be accorded to all humans regardless of their socio-economic status. Therefore, the present study at hand details the challenges of accessing higher education in Ghana and students' coping strategies. Qualitative research methodology with interviews, focus group discussion and auto-ethnography was employed as major instruments for data collection. Document review was used to understand the cost of pursuing university education in Ghana. The results indicated that majority of students who enroll, persist and graduate in Ghanaian universities are economically advantaged students. These students are beneficiaries of high quality education coupled with good resources in the urban areas from primary education. The plight of majority of Ghanaian population who depends on agriculture in rural areas with less quality of education is rare in Ghanaian universities. Moreover, there are government financial support systems for the needy students such as Student Loan Trust Fund (SLTF) but this financial assistance has its own challenges which impedes greater accessibility. From the findings gathered, it can be concluded that university education in Ghana is more of a privilege than right. In the light of this, the study suggest that stakeholders and educational legislators in Ghana should develop feasible policies that considers the economically-disadvantaged students who qualify for university education but unable to access it due to inadequate resources.

Keywords: university education; students; cost; economic disadvantaged; privilege 


\section{University education in Ghana: a privilege or a right?}

\section{Introduction}

The convention on the rights of the child in 1989 and the world declaration on Education For All (EFA) in 1990 reaffirmed education as a human right (EFA Global monitoring report, 2015). Education is a fundamental human right and it promotes individual freedom and empowerment and yields important development benefits (UNESCO, 2014). In stressing the importance of education, Igbuzor (2006) stated that education is a human right that should be accorded to all humans solely by reasons of being humans. The 1960 UNESCO Convention against Discrimination in Education (CADE) sanctions duties and actions for the state to make sure higher education is equally accessible to all on the basis of individual capacity (UNESCO, 2014). Education has to be flexible and adaptable to the needs of changing societies and responding to the needs of students within their diverse social and cultural settings (UNESCO, 2014). In 2009 UNESCO World conference on higher education in Paris adopted the resolution that higher education is a public good (Morley, 2012). Similarly, EFA underscores the critical role of education to the development of knowledge and skills of people for a socially progressive society and a vibrant knowledge based economy (Tagoe, 2014).

Even though education is a human right and that it must be accessible to all, in Ghana, education seems to be a privilege for the rich. Many qualified students are denied access based on their social economic status. Atuahene and Owusu-Ansah (2013), noted that access has not been broadened to include all social groups. These scholars revealed that even though Ghana has made tremendous improvement in terms of participation rate in the universities, there are evidence that greater percentage of students are excluded from participating in tertiary education. For regular students, even though higher education is free, still there exist several charges such as registration fee, technology fee, examination fee, academic facility user fee, medical services fee, venture capital fee etcetera that make it very expensive for individuals from low socio-economic status to afford participation. Worse still, with the current Ghanaian economy, a greater percentage of students cannot manage to access education without government subsidies. In 2011, the World Bank estimated that male students from highest income quintile are more than 7times likely to successfully enter and complete university education in Ghana than their counterparts from poorest quintile (Atuahene, 2014). Atuahene further notes that students enrolled in the universities are from the economically advantaged regions of the country.

\subsection{Background}

The provision of education centered on the elite in the society which comprised the mulattos, sons of local chiefs and wealthy traders. The emergence of the Wesleyan and Basel Mission in the $19^{\text {th }}$ century widened the participation of education by establishing schools that allowed for inclusive education (Graham, 1971). Several educational reformations have been experienced until the establishment of University of Ghana in 1948, the then University College of Gold Coast. Currently, Ghana can boast of 10 public Universities, 8 private and 37 public colleges of education, 5 private and 23 public nursing training colleges, 11 tutorial colleges, 1 college of Agriculture institution, 4 private chartered tertiary institutions, 5 professional institutions and 10 regional polytechnics where 6 is currently converted to be Technical Universities and to be running the BTect programs (National Council for Tertiary Education, 2016).

It is an undeniable fact that, higher education is the backbone of every country's economy. Its effective implementation and utilization enhance poverty alleviation, improvement in public health care and development of human capital (Amenyah, 2009). Despite these merits, higher education in Ghana encounters challenges that prevent it from achieving complete success. Insufficient funds from government and other stakeholders that enable subsidization of cost have created an abyss for higher education accessibility. Also, as a result of high population growth, institution's facilities are not adequate enough to accommodate the few students that get 
access to higher education. There is lack of expansion of infrastructure to cater for prospective students aspiring for admission. To date, the provision of education seems to center on the elite in the society as it used to be during the time of the mulattos, sons of local chiefs and wealthy traders, questioning the nature of education as a human right and a public good. Nonetheless, the constitution of Ghana emphasizes that:

Higher education shall be made accessible to all on the basis of capacity by every appropriate means and in particular by progressive introduction of free education. The state shall, subject to the availability of resources provide......... equal access to equivalent university education with emphasis on Science and Technology (Ghana Constitution, 1992, Article 25: 1C; 38 [3]).

However, the current trend of higher education in Ghana skates on a different vision parallel to the provision of the constitution. This stems from the fact that high cost of higher education has rendered most economic disadvantaged students incapable of accessing university education. This has greatly created a huge vacuum between the rich and the poor making education in Ghana more of a privilege than a right. Although several studies have been conducted on accessibility of higher education in Ghana (Atuahene, 2014; Atuahene \& Owusu-Ansah, 2013; Dadzie, 2009; Amenyah, 2009), much has not been done on whether university education is a privilege or right.

With this background, this study seeks to explore the cost of university education in Ghana. The rationale is premised on the fact that education is a human right which must be accorded to all humans regardless of their socio-economic status. As sub questions, the study seeks to explore the challenges with regards to having access to higher education in Ghana and students coping strategies with the challenges.

\section{Methods}

The researchers employed qualitative methodology as a research design to collect and present data. This method investigates a contemporary phenomenon and within its real life context (Yin, 2009). According to some renowned scholars in the field of qualitative research, purposeful selection is an instrument which cannot be overlooked in sampling data (LeCompte \& Preissle, 1993; Patton, 2002). Patton (2015) also suggests that purposeful sampling is a means of "selecting information-rich cases to study, cases that by their nature and substance will illuminate the inquiry question being investigated" (p. 264). This sampling approach is adopted by the researcher to gain detailed insights and understanding of selected participants in the study.

Data for the study was collected through in-depth interviews, focus group discussion, auto-ethnography, and through document review. Interviews are flexible and allow multi-sensory channels to be used such as non-verbal cues (Patton, 2015). These tools were used as they give room for probing, question and answer clarification. With regards to the focus group discussions, participants were allowed to participate in the discussion where the topic about university affordability in Ghana was introduced. Guiding questions were developed and participants were controlled to remain within the course of the topic. Based on the questions, participants shared their views and understanding about university education in Ghana.

The interviews and focus group discussions were conducted with university students and alumni from university institutions in Ghana. Auto-ethnography was also used to discuss the personal experiences of university access and challenges in Ghana as one of the researchers is from Ghana. Some documents regarding university education policies and reforms were also reviewed. These deepen our understanding of the issue under investigation. The use of different methods to collect data ensured credibility of the data through triangulation (Maxwell, 2009). The study used convenience sampling techniques to identify the research participants. Before setting out for the study, the researchers piloted the interview questions which were semi structured in nature with six university students.

Data collected was read through and transcribed to obtain a general sense of the information as recommended by Creswell (2009). The aim was to obtain repeated phrases and words. Based on research 
questions, detailed analysis was done to understand student experiences of university education in Ghana. This involved taking text data, segmenting them into categories and then labeling those categories with the term, usually a theme. Then description about the themes was done and the themes appeared as major findings of the study. To ensure privacy, no name of participant has been revealed anywhere in this document.

\section{Findings and Discussions}

\subsection{Forms of University Education in Ghana}

Before discussing the cost of university education in Ghana, it was felt necessary to first understand the forms of university education in Ghana. The study found that university education in Ghana has two main forms by virtue of ownership which are private and public universities. Both categories of university offer regular, distance learning and sandwich programs at various levels. The sandwich and distance learning programs are mostly patronized by students who are interested in pursuing education but cannot exempt their work and bear the cost of regular education. As such, they sort programs organized during weekends and vacations. For example, this participant stated "though I have the qualifications that can enable me pursue regular university education, I cannot afford the cost if I abandon my work". This finding was not surprising as Mensah et al. (2002) asserted that Distance Education Learning (DEL) allows working adults to combine work while studying.

The study has further revealed that there are some students non-workers who participate in distance and sandwich programs instead of attending regular education. As discussed later, the reasons are mainly related to high cost of regular education. For example, this participant argued, "I decided to be a distance education student because I cannot afford to accommodate and feed myself on campus". Most Ghanaian students are left to fend for themselves after attaining Senior High School education. Majority of them have no secure jobs but have passion for continuing their education to the university level. They have no option than to use their scanty salary to pay for their fees through Distance Education Learning.

Cost of University Education - The cost of university education in the world is relatively high. The study has similarly found that the cost of attaining university education in Ghana is exceedingly high. Unlike in the other parts of the world however, the cost of university education in Ghana could be understood in four perspectives.

First, majority of people in Ghana depend on rain fed agriculture with less than $43.1 \%$ (Powell, 2015) working in the government sector. Consequently, the income realization of people in the country is extremely low. Due to this, parents find it difficult to finance education of their wards to the highest level as the cost of education continues to increase with less state subsidies. This means that even though their kids might qualify for university education, many parents cannot afford the required fees. In effect, most of them do not even attempt to apply for admission.

Second, most students that access university education in Ghana come from high schools located in urban areas than rural areas. According to the participants, this is as a result of better teaching and learning facilities in urban high schools compared with rural schools. Students in urban schools therefore perform better and qualify for university education compared to those that attend rural schools. Interestingly, most of these better urban high schools are privately owned and are very expensive for an average Ghanaian citizen. This means that, only students from the 'rich' families manage to attend these private schools and subsequent university education. This cements the argument stipulated by Opoku-Asare (2015) that, student who attend well-furnished institutions in the urban area are able to perform better than their counterpart that attend rural institutions with less resources and hence proceed with their university education.

In relation to this, findings from some renowned researchers also indicate that students in rural or deprive schools have limited access to quality education (Mitchell, 2006; Morley et al., 2010; UNESCO-UIS, 2009, 2011; 
Mama, 2003 cited in Opoku-Asare, 2015). Atuahene and Owusu-Ansah (2013) further argue that largest population of students in higher education originates from urban regions and cities with highly resourced and facilitated high schools. Such institutions enhance the affordability of the rich depriving the poor from attending such schools. Similarly, Opoku-Asare and Siaw (2015) stipulated that:

students who have opportunity to attend one of the top-ranked secondary schools which are staffed with quality teachers and have comparatively better educational facilities tend to perform better than their peers who attend mediocre Senior High Schools that are predominantly located in rural areas in historically disadvantaged regions of the country, which have substandard academic infrastructure or facilities (p. 4)

Third, the cost of admission fee is very high for an average Ghanaian. For example, in 2015/16 academic year, the admission fee for University ' $\mathrm{A}$ ' was $\mathrm{GH} \phi 1850$ (about \$483). As such, considering the cost of admission fees coupled with unforeseen expenses discourage most students and parents.

Again, the cost of some course materials which usually inflate fees are necessary irrelevant for some students. Adding tablet (iPad) as a compulsory course material for students pursuing Distance Education program is not equally significant for every students. Though, the usage of technology cannot be eschewed in the current fast growing technology world but its incorporation into education should not be detrimental to students' accessibility to education. As stated by another student "the cost of admission fee for my program is not outrageous if cost such as tablet/iPad is excluded from the list of course materials. Sometimes, it will be convenient for others to pursue higher education if some conditions are made flexible for students to decide for themselves. If we have the idea of improving students' participation and success in higher educational institutions, then we have to consider what factors attract, retain and attrite students in higher educational institutions.

A distance education student at University 'B' argued that due to high cost of fees most of his course mates have deferred their program. This student further stated that, others with no other choice have quitted the program entirely in pursuit of other cheaper undertakings in which they can manage. However, this means that those who quit the programs are brilliant but needy students who cannot afford university education. He stipulated during the interview that "I had to borrow GHф5800 (\$1,471) to pay user fees. The figure above just represents a fee for 2 semesters as a distance Computer Engineering students. As a matter of fact, an average worker who receives a monthly salary of $\phi 1,400$ (\$355.22) will find it difficult to afford such cost of education without external support.

To ensure the persistence number of students that get enrolled in universities, some institutions have adopted measures that seem to benefit only the rich. For example, some institutions do not allow for admission of students who are not full time or part time workers. This student reported, "In my school for example, it is part of the admission requirement to be a worker (minimum of 2 years working period) before you can be considered for admission". Such policies are enacted in some institutions to ensure that persistence rate in university education is sustained. Institutions understand that even though some students are withdrawn on academic grounds, failure to pay tuition fees is a cause for high attrition rate. This participant stated:

In 2014, about 63 students were admitted in computer engineering, 7 students were withdrawn for non-performance and 14 students were compelled to defer or stop their education due to their inability to meet tuition demands. About half 42 remaining students have not fully paid off their fees for the said academic year.

Again, an observation of higher educational institutions in Ghana revealed that, the cost of education depends on a particular program of study in an institution. Huge variation in cost exists between Science and Humanities programs. Programs such as Medicine, Engineering and Computer Science are more expensive than Social Science programs such as Education, Psychology, and Business programs. The situation still remains 
unclear as who pursue Humanities and Science programs on the grounds of equal intellectual ability and at what cost? In a more significant analysis, if education is not a privilege, why should low performing students be offered the chance for pursuing the so called 'fee paying' programs irrespective of their abysmal performance in a more difficult and challenging programs such as Medicine, Engineering and Computer Science whiles the brainy but needy students become stuck at home due to lack of funds (Dadzie, 2009). In a clearer way, the needy students pursue Social Sciences programs than their counterparts. From this point, it can be deduced that, the role of education which seek to harmonize the society ends up creating disparity between social classes. The rich continue to expand their wealth through the use of education as an instrument of empowerment whiles the poor remain stagnant because there is little effort to improve their condition.

\subsection{Support systems}

The cost of tertiary education is incredibly high in most countries in relation to the demand for quality, greater accessibility and impartial equality. However, variations exist as a result of availability of support systems provided by government and other stakeholders of an institution. European countries like Denmark, Finland, Norway, Germany and Sweden offer opportunities to study for tuition free in public universities but small nominal university fee is charged to cover administration costs (Marcucci, 2012). Contrary, countries such as Brazil, Ukraine, United Kingdom, United States, Uganda, and Kenya had to increase resources on non-public sources to support administrative running of tertiary education due to excessive governmental cut fund (Marcucci, Johnstone, \& Ngolovoi, 2008). In such situations the cost of tertiary education is comparatively high making affordability of education for only the fortunate students who can purchase to some point. China for example has increased its funding system in their higher education due to the implementation of 211 and 985 policies. Such massive subsidization encourages less payment of tuition and user fees hence improving participation of higher education by the general public (Gu, 2012).

In Ghana, financial assistance is provided to students who are financially handicapped to cope with cost of university education. Monetary support generally covers user fees, cost of administration and living expenses, thereby ensuring that qualified low-income students are not excluded from pursuing tertiary education due to insufficient resources. Financial assistance is sometimes also used to encourage higher education participation by underrepresented minority groups, or to encourage the study of certain disciplines. Accessing the financial aid (SLTF) is not difficulty but the system has its own challenges that demotivate students' utilization. This is coupled with the facts that the amounts are usually not sufficient to cater for fees alongside the huge accumulated interests and issues of default repayment (Atuahene, 2007). To buttress the point further, most students are confronted with the challenge of accessing the facility due to lack of guarantors and fear of future unemployment crisis. Regular students interviewed at Winneba campus could not hide their feelings and said:

There has been an embargo on public sector employment for the past three years, what is the assurance that my hard earned certificate will grant me employment to enable me pay for a student loan. Our guarantors are growing extinct in endorsing our loan because there is lack of hope for employment that can recover the loan.

To some extent, the inception of Distance Education in Ghana has facilitated the reduction of university education as an opportunity for the elite. Though Distance Education and Sandwich programs have increased participation to some point the cost is very unbearable for some students.

Students are willing to pursue their higher education and contribute to the development of their societies. However, the current conditions coupled with the uncertainties over the prospect of employment after graduation places them in difficult circumstances. The Vice Chancellor of University of Cape Coast and member of the Association of African Universities (AUU) Governing Board (Prof, Domwini Dabire Kuupole) mentioned during the 2015 annual general report (AGM) of Association of African Higher Education Financing Agencies (AAHEFA) that students loans, grants and scholarships have become the only option for intelligent but 
disadvantaged students to enhance participation in higher education. In a statement delivered by another Board Member of Student Loan Trust Fund in the same report suggested that, Africa must plan to transform its population into national assets that will feed global Labor demands as the continent's population is projected to reach 2.5 billion by the year 2050 (AAHEFA annual conference report, 2015). This can effectively be achieved when students' loan scheme is effectively implemented and addressed the current challenges that threaten the participation of poverty stricken citizens of the country (Dadzie, 2009). Even though education as a privilege was challenged and was affirmed to be a right in 1948, evidences from Ghana indicates that education continues to be a privilege. Privilege is a particular and peculiar benefit or advantage enjoyed by a person, company, or class, beyond the common advantages of other citizens (Ayyad \& Fatma, 2015).

\section{Conclusion: Is university education in Ghana a privilege or right?}

As evidenced from this study, students are compelled to withdraw because of lack of user fees. Some institutions require students to have a job as a precondition for enrollment. Those with no jobs are definitely left out. In other circumstances, students do not see the need to acquire a certificate which cannot grant them promising jobs after spending huge sums of money on education. Similarly, those in rural areas are poorly under-represented in universities due to inadequate facilities in their high schools. Even if they perform better and get enrolled in the universities, they withdraw due to high cost of Academic User Fees (AUFs). As such, many students who have the intellectual capacity to attend higher institution in Ghana fail to do so. This however operates against the constitutions of Ghana which states that higher education shall be made accessible to all and that it shall provide equal access to equivalent university education (Ghana Constitution, 1992, Article 25: 1C; 38 [3]). If higher education was a right, it was the expectation of the society that everyone has eligible access into tertiary education. This brings to mind that, a right is something that you do not need to seek permission before accessibility. On the other hand, the gate keeping system in our institution is too rigorous for easy accessibility of higher education. Consequently, education is a privilege rather than a right.

\subsection{Suggestions}

Stakeholders and educational legislators in Ghana must develop feasible policies that considers the economically-disadvantaged students who qualify for university education but unable to access it due to inadequate resources.

Loans and other financial facilities should be channeled into the higher education program because the gap between the enrollment rate of high school and tertiary education is highly incomparable. Government and other stakeholders of education should not relent on their effort for achieving minor significant success of Student Trust Fund initiatives. There should be more collective effort between the state and parents as to how best to support each other in accessibility of higher education. The scholarships, grants and donations should be provided for our poor, needy but brilliant students who cannot pursue higher education due to lack of funds.

Admission policies should consider the plight of students in rural areas with inadequate learning opportunities than those in the urban centers. It is undeniable fact that some higher educational institutions are already doing well on this, however more focus should be highlighted on policies regarding admission for rural students. Research indicates that students recruited from rural schools do better than their counterparts from urban centers. Though their grades may be low but given the same opportunity encourage them to perform better when the right conditions are met.

Moreover, institutions should view students as customers who need to be treated with care and dignity. The mere fact that the numbers of students outpace the universities entrant does not give impetus for students to be handled anyhow. The absence of students in institutions means no value for faculty members, administrators and other staffs. Flexible admission policies should be practiced where students can be given the opportunity to decide course materials and other facilities relevant for their academic and social development. Administrators 
Acheampong, P., \& Kayange, J. J.

must bear in mind that they are not in position for their interest but to serve the needs and interest of students.

\section{References}

Amenyah, A. M. (2009). Higher education in Ghana. Retrieved from http://www.ghanaweb.com/GhanaHomePage/features/Higher-Education-in-Ghana-160902

Association of Africa Higher Education Financing Agencies annual conference report. (2015) Retrieved from http://www.aahefa.org/

Atuahene, F. (2007). The challenge of financing higher education and the role of student loans scheme: An Analysis of the Student Loan Trust Fund (SLTF) in Ghana. Higher Education, 56, 407-421. http://dx.doi.org/10.1007/s10734-007-9101-5

Atuahene, F. (2014). Charting higher education development in Ghana: Growth transformations and challenges. International Perspective on Education and Society, 21, 215-263. http://dx.doi.org/10.1108/S1479-3679(2013)0000021011

Atuahene, F., \& Owusu-Ansah, A. (2013). A descriptive assessment of higher education access participation, equity and disparity in Ghana. SAGE Open, 1-16. http://dx.doi.org/10.1177/2158244013497725

Ayyad, F. (2015). Higher education and privilege: 21st century issues. College Student Affairs Leadership, 2(2) $2332-4430$.

Creswell, J. W. (2009). Research design: Qualitative, quantitative, and mixed methods approaches (3rd ed.). London: Sage.

Dadzie, D. S. (2009). Cost sharing and equity in higher education: Experiences of selected Ghanaian students (Unpublished dissertations). Ohio University.

EFA Global monitoring report. (2015). Education for all 2000-2015: Achievements and challenges. Paris: United Nations Scientific and Cultural organization.

Graham, C. K. (1971). The history of education in Ghana: From the earliest time to the declaration of independence. Milton Park: Frank Cass and Company Limited.

Gu, J. (2012). Spatial recruiting competition in Chinese higher education system. Higher Education, 63, 165-185. http://dx.doi.org/10.1007/s10734-011-9429-8

Igbuzor, O. (2006). The state of education in Nigeria. Action Aid International Nigeria. A keynote address delivered at a roundtable organized by civil society action coalition on education for all (CSACEFA).

Johnstone, D. B. (2003). Cost-sharing in higher education: Tuition, financial assistance, and accessibility. Czech Sociological Review, 39(3), 351-374.

LeCompte, M. D., \& Preissle, J. (1993). Ethnography and qualitative design in educational research. New York: Academic Press, Inc.

Marcucci, P. D., Johnstone, B., \& Ngolovoi, M. (2008). International issue. Peabody Journal of Education, 83(1) 101-116.

Marcucci, P., \& Usher, A. (2012). 2011 year in review: Global changes in tuition fee policies and student assistance. Toronto: Higher Education Strategy Associates.

Maxwell, J. A. (2009). Designing a qualitative study. In L. Bickman \& D. J. Rog (Eds.), Applied social research methods (pp. 214-253). Thousand Oaks, CA: Sage Publications. http://dx.doi.org/10.4135/9781483348858.n7

Mensah, K. E. S., \& Owusu-Mensah, F. (2002). Priorities and strategies for capacity building in tertiary distance education for human resources development in Ghana. A final report prepared for the World Bank. Paris: World bank.

Morley, L. (2012). Experiencing higher education in Ghana and Tanzania: The symbolic power of being a student. In T. Hinton-Smith (Ed.), Widening participation in higher education (pp. 245-2662). Palgrave: Macmillan.

National Council for Tertiary Education. (2016). Leading tertiary education to greater heights. Retrieved from http://www.ncte.edu.gh/

Opuku-Asare, N. A., \& Siaw, A. O. (2015). Rural-urban dissparity in students academic performance in visual 
arts education: Evidence from six senior high schools in Kumasi, Ghana. SAGE Open, 1-14.

Patton, M. Q. (2002). Qualitative research \& evaluation methods (3rd ed.). Thousand Oaks, CA: Sage Publications.

Powell, B. J. (2015). Factors affecting growth in Ghana's services economy. U.S International Trade Commission, (Executive briefings on trade).

Tagoe, M. A. (2014). Making real the dream of education for all through open schooling and open universities in Ghana. SAGE Open, 1-12. http://dx.doi.org/10.1177/2158244014559022

UNESCO. (2014). The right to education; Law and policy review guidelines. Paris, France: UNESCO.

Yin, R. K. (2009). Case study research, design and methods (4th ed.). London: Sage. 
Acheampong, P., \& Kayange, J. J. 